\title{
Evaluation of the Lifetime Cancer Risk Due to Natural Radioactivity in Tap Water Consumed in Nevşehir Province, Turkey
}

\author{
Aybaba HANÇERLİOĞULLARI*, Şeref TURHAN, Aslı KURNAZ \\ Kastomunu University, Faculty of Science and Letters, Department of Physics, 37150, \\ Kastamonu, Turkey \\ (ORCID: 0000-0001-7008-480X)(ORCID: 0000-0001-5303-3680) (ORCID: 0000-0002-7910-3461)
}

\begin{abstract}
Ionizing radiations ( $\alpha$-, $\beta$ - and $\gamma$ - rays) emitted from radionuclides in waters can produce detrimental biological effects for human health. The excess lifetime cancer risk (ELCR) relates to the probability of developing cancer over a life-time at a given annual exposure dose rate. In this study, the excess lifetime cancer risk was evaluated for adults living in Nevşehir province based on the contents of gross alpha and gross beta in tap water samples collected from various districts in Nevşehir. The values of the excess lifetime cancer risk varied $1.7 \times 10^{-4}$ to $1.3 \mathrm{x}$ $10^{-3}$ with an average of $5.5 \times 10^{-4}$. Consequently, the ELCR values via tap water consumption were found below the acceptable limit of $10^{-3}$ for radiological risk.
\end{abstract}

Keywords: Tap water, The excess lifetime cancer risk, Nevşehir.

\section{Türkiye Nevşehir İlinde Tüketilen Musluk Suyunda Doğal Radyoaktivite Nedeniyle Yaşam Boyu Kanser Riskinin Değerlendirilmesi}

\section{Öz}

Sularda radyonüklitlerden yayılan iyonlaştırıcı radyasyonlar ( $\alpha$-, $\beta$ - ve rays-1şınları) insan sağlığı için zararlı biyolojik etkiler yaratabilir. Yaşam boyu kanser riski (ELCR), verilen yıllık maruz kalınan doz oranında yaşam boyu kanser gelişme olasılığı ile ilişkilidir. Bu çalışmada, Nevşehir ilinde yaşayan yetişkinler için yaşam boyu kanser riski, Nevşehir'in çeşitli ilçelerinden toplanan musluk suyu örneklerinde toplam alfa ve toplam beta içeriğine göre değerlendirilmiştir. Yaşam boyu kanser riskinin değerleri ortalama 5.5 x 10-4 olmak üzere 1.7x104 ile 1.3x10-3 arasında değişmiştir. Sonuç olarak, musluk suyu tüketimi yoluyla ELCR değerleri radyolojik risk için kabul edilebilir 10-3 sınırının altında bulunmuştur.

Anahtar kelimeler: Musluk suyu, Yaşam boyu kanser riski, Nevşehir

\section{Introduction}

Water is a necessary food for human life. Therefore, every effort that is applicable as safe as possible has been made by the WHO and the relevant institutions/organizations of each country to obtain drinking water [1]. Water pollution occurs when undesirable substances enter into water [1]. Diseases due to the pollution of drinking water cause serious problems in humans. Therefore, interventions to enhance the drinking water quality procure important health benefits.

The main sources of water pollution can be grouped into three groups as biological (microbial) pollutants, chemical pollutants, and radiological pollutants [2]. Some of these chemicals are (a) carcinogenic (b) perhaps carcinogenic, (c) possibly carcinogenic, (d) not classifiable as to its carcinogenicity and (e) likely not carcinogenic to humans [1]. Some chemical elements such as uranium, thorium, and potassium naturally occurring in the environment are radioactive [3]. In addition, the world is constantly bombarded by high-energy particles from both the sun and the outside of the solar system

*Sorumlu yazar: aybaba@ kastamonu.edu.tr

Geliş Tarihi: 15.10.2019, Kabul Tarihi: 19.12.2019 
known as cosmic radiation. Artificial radioactive sources consist of (a) radionuclides used for different purposes in medicine (diagnosis and treatment), agriculture and industrial activities and (b) radionuclides released directly into the atmosphere after a total of 543 atmospheric nuclear weapons conducted between 1945-1980 years and the nuclear power plant accidents [4]. In addition, radon $\left({ }^{222} \mathrm{Rn}\right)$ gas, which is a radioactive decay product of radium $\left({ }^{226} \mathrm{Ra}\right)$ in drinking water entering into the body through the respiratory tract, may increase the risk of lung cancer over time [4].

Risk evaluation is a method used to evaluate the likelihood that exposure to radionuclides will harm people or the environment. The purpose of this study is to evaluate the radiation risks due to the ingestion of tap water from different sources in Nevşehir province. Therefore, in this study, the annual effective radiation dose and ELCR caused by the natural radioactivity in tap water samples collected from Nevşehir province were estimated.

\section{Material and Method}

The ELCR was estimated based on the annual effective dose rate using the equation [5]:

$E L C R=A E D R \times A H L \times F R$,

where $A E D R$ is the effective dose rate, $A H L$ is the mean human life of 78 years for Turkish adult person and FR is risk factor given to be 0.057 per Sievert ( $\mathrm{Sv}$ ) for stochastic effects produced low background radiation [6]. In estimation of the ELCR, the values of AEDR were taken from the study performed Turhan et al. [7]. Also, the values of the AEDR varied from 38 to $288 \mu \mathrm{Sv} / \mathrm{y}$ (average: $124 \mu \mathrm{Sv} / \mathrm{y}$ ) [7].

\section{Results and Discussion}

The excessive lifetime cancer risk due to alpha and beta emitting radionuclides in twenty-one tap water samples collected from Nevşehir city center are given in Table 1. It is seen from Table 1 that The CR values varied from $1.7 \times 10^{-4}$ to $1.3 \times 10^{-3}$ with an average of $5.5 \times 10^{-4}$. The highest value of the CR was estimated for tap water, TWS1 while the lowest value of the CR was estimated for tap water, TWS5. The ELCR average value is approximately three times lower than the world average of $1.6 \times 10^{-3}$ while all CR values were below the world average value [3].

\section{Conclusions}

The aim of this study was to provide information for the Nevşehir region. The results obtained show that the ELCR values are lower than the world's mean value. The present study provides a general background and can be used as a baseline for future investigations.

Table 1. The excess lifetime cancer risk estimated for the tap water samples

\begin{tabular}{ll} 
Sample code & CR \\
\hline TWS1 & $1.3 \times 10^{-3}$ \\
TWS2 & $7.1 \times 10^{-4}$ \\
TWS3 & $5.2 \times 10^{-4}$ \\
TWS4 & $5.6 \times 10^{-4}$ \\
TWS5 & $1.7 \times 10^{-4}$ \\
TWS6 & $3.8 \times 10^{-4}$ \\
TWS7 & $2.7 \times 10^{-4}$ \\
TWS8 & $5.5 \times 10^{-4}$ \\
TWS9 & $4.7 \times 10^{-4}$ \\
TWS10 & $4.2 \times 10^{-4}$ \\
TWS11 & $4.3 \times 10^{-4}$ \\
TWS12 & $4.8 \times 10^{-4}$ \\
TWS13 & $2.7 \times 10^{-4}$ \\
TWS14 & $5.4 \times 10^{-4}$ \\
TWS15 & $7.1 \times 10^{-4}$ \\
TWS16 & $5.7 \times 10^{-4}$ \\
TWS17 & $7.6 \times 10^{-4}$ \\
TWS18 & $6.8 \times 10^{-4}$ \\
TWS19 & $8.0 \times 10^{-4}$ \\
TWS20 & $5.1 \times 10^{-4}$
\end{tabular}




\section{References}

\begin{tabular}{ll} 
TWS21 & $5.0 \times 10^{-4}$ \\
\hline Average & $5.5 \times 10^{-4}$ \\
Standard deviation & $2.3 \times 10^{-4}$ \\
Standard error & $5.0 \times 10^{-5}$ \\
Min & $1.7 \times 10^{-4}$ \\
Max & $1.3 \times 10^{-3}$ \\
\hline
\end{tabular}

[1] WHO (World Health Organization). 2011. Guidelines for Drinking-water Quality. 4th edition, WHO Library Cataloguing-in-Publication Data NLM classification: WA 675, Geneva.

[2] Zriba N. 2019. Determination of Radiological and Chemical Aspects of Packaged Drinking Waters Consumed in Cappadocia region. Kastamonu Üniversitesi, Fen Bilimleri Enstitüsü, Yüksek Lisans Tezi, Kastamonu.

[3] UNSCEAR (United Nations Scientific Committee on the Effects of Atomic Radiation). 2000. Sources and effects of ionizing radiation. United Nations Publication, New York, USA.

[4] Özçıtak E. 2012. Nevşehir ili ve ilçelerinde tüketilen içme ve kaplıca sularındaki radyoaktivitenin ölçülmesi. Nevşehir Ü, Fen Bilimleri Enstitüsü, Fizik Anabilim Dalı, Yüksek Lisans Tezi, Nevşehir.

[5] Ezekiel A.O. 2017. Assessment of excess lifetime cancer risk from gamma radiation levels in Effurun and Warri city of Delta state, Nigeria. Journal of Taibah University for Science, 11: 367380.

[6] ICRP, 1991. 1990 Recommendations of the international commission on radiological protection. ICRP Publication 60, International Commission on Radiological Protection (ICRP). http://www.icrp.org/publication.asp?id=ICRP+Publication+60.

[7] Turhan Ş., Zriba N.A.E.M., Taşkın H., Yılmaz Z., Bayülken S., Hançerlioğulları A., Kurnaz A. 2019. Radiochemical analysis of bottled drinking waters consumed in Turkey and a risk assessment study. Microchemical Journal, 149. 